\title{
Metaphors with Translingual Dimensions in the Novels of Khaled Hosseini
}

\author{
Abdul Wadood Khan \\ Department of English Language and Translation \\ College of Languages and Translation \\ King Saud University, Riyadh, Saudi Arabia
}

\begin{abstract}
This study addresses the phenomenon of literary bilingualism by investigating the simultaneous interplay of multiple discourses and languages in Khaled Hosseini's novels. It primarily focuses on metaphors in his fiction, which lend a unique sense of translingualism and multiculturalism to his work. Hosseini's overt and covert use of metaphors reveals an allegiance to several languages that are spoken in Afghanistan and the region, including Pashto, Persian, Arabic and Urdu. His double cultural and discursive belonging suggests a case for post-structural translingualism, a fluid bilingualism belonging simultaneously to all the languages in one's repertoire. These metaphors, along with his characteristic narrative and linguistic strategies, give Hosseini a unique linguistic persona. This study addresses, inter alia, the self-translating aspect of Hosseini as an author whose works remain marvels of interwoven languages and identities.
\end{abstract}

Keywords: khaled hosseini, metaphor, multiculturalism, multilingualism, translingualism

Cite as: Khan, A. W. (2017). Metaphors with Translingual Dimensions in the Novels of Khaled Hosseini. Arab World English Journal for Translation \& Literary Studies, 1(4). DOI: http://dx.doi.org/10.24093/awejtls/vol1no4.13 